\title{
RESPON PERTUMBUHAN SEMAI GAHARU (Aquilaria malaccensis) TERHADAP PEMBERIAN PUPUK ORGANIK
}

\section{(Seedling Growth Response of Agarwood-Producing Tree Species of Aquilaria malaccensis towards Organic Fertilizer Application)}

\author{
Oktovina Dorce Inggesi ${ }^{1}$ Amilda Auri ${ }^{1 \bowtie}$ dan Petrus A. Dimara ${ }^{1}$ \\ Jurusan Kehutanan, Fakultas Kehutanan Universitas Papua Manokwari, Papua Barat, \\ 98314. Tlp/Fax: +62986211065. \\ \enulis Korespondensi: Email: amildaauri@gmail.com \\ Diterima: 05 Sept 2019| Disetujui: 20 Sept 2019
}

\begin{abstract}
Abstrak
Tujuan dari penelitian ini adalah untuk mengetahui respon pertumbuhan semai gaharu (Aquilaria malaccensis) terhadap pemberian pupuk organik melalui penggunaan metode eksperimen rancangan percobaan lengkap (RAL) dengan total 180 unit percobaan. Hasil penelitian respon pertumbuhan semai gaharu menunjukkan tidak ada perbedaan yang nyata antara ketiga perlakuan yang diberikan terhadap pertambahan tinggi semai gaharu dengan nilai $\mathrm{F}$ hitung 2,196 lebih besar dari pada signifikannya yaitu 0,192 . Rata-rata pertumbuhan diameter tertinggi dimiliki oleh perlakuan kontrol yaitu $0,037 \mathrm{~cm}$ sedangkan perlakuan media campuran pupuk kandang dan top soil dan media campuran pupuk kandang, EM4+ dan top soil memiliki nilai rata-rata pertumbuhan yaitu 0,09 dan $0,08 \mathrm{~cm}$. Hasil penelitian menunjukkan bahwa tidak ada perbedaan yang nyata antara tinggi, diameter dan percabangan tanaman pada ketiga perlakuan yang diberikan.

Kata kunci: Aquilaria malaccensis, respon pertumbuhan, pupuk, rancangan percobaan, pertumbuhan semai

Abstract

This study aims at perceiving a growth response of agarwood-producing tree species of Aquilaria malaccensis towards organic fertilizer treatments through complete random design experiment with a total of 180 trial units. The result of seedling growth response showed no significant differences among the three given treatments toward high growth of agarwood-producing species of A. malaccensis with a bigger f-value of 2.196 than its significance of 0.192. The highest average diameter growth has been indicated by control of $0.037 \mathrm{~cm}$, while a combined treaments of manure and topsoil as well as manure, EM4+ and topsoil had the average growth of 0.09 and $0.08 \mathrm{~cm}$ respectively. In addiiton, there was no significant difference between height, diameter, and branch of the plant from the three given treatments.
\end{abstract}

Keywords: Aquilaria malaccensis, growth response, fertilizer, experiment design, seedling growth 


\section{PENDAHULUAN}

Indonesia adalah produsen gaharu terbesar di dunia dan menjadi tempat tumbuh endemik beberapa spesies gaharu komersial (Situmorang dan Yupi 2006). Gaharu merupakan salah satu jenis flora yang memiliki berbagai manfaat dan komoditas elit hasil hutan bukan kayu (HHBK) karena bernilai tinggi dan banyak diminati oleh masyarakat. Menurut Sumarna (2005), jenis ini banyak diminati karena mengandung damar wangi berupa Oleoresin yang akan mengeluarkan aroma khas bila dibakar.

Jenis-jenis pohon yang dapat menghasilkan gubal gaharu adalah pohon-pohon yang termasuk dalam famili yaitu famili Thymeleacea, Leguminoceae, dan Euphorbiaceae (Didimus dalam Winarsih dkk. 2011). Jenis tanaman yang dapat menghasilkan gubal gaharu dengan kualitas expor adalah tanaman yang berasal dari genus Aquilaria spp., (Sumarna 2007). Komisi CITES tahun 2004 telah menetapkan Aquilaria spp., dan Gyrinops spp., masuk dalam daftar tumbuhan Apendix II CITES (Nursin dalam Sumarna 2012) artinya pohon tersebut layak dilindungi, dibudidayakan, dan dilarang penebangan tanpa mengantongi surat izin dari CITES (Departemen Kehutanan 2004). Pohon gaharu tersebar di Sumatera, Kalimantan, Sulawesi, Nusa Tenggara, Maluku dan Irian Barat. Dalam pertemuan ke-13 Convention on International Trade in Endangered Species of Wild Fauna and Flora (CITES) di Bangkok tanggal 2-14 Oktober 2004, genus Aquilaria spp., telah dimasukan dalam Appendix II. Artinya, Seiring perkembangan ilmu pengetahuan dan teknologi industri, gaharu bukan hanya berguna sebagai bahan untuk industri wangi-wangian saja, tetapi juga secara klinis dapat dimanfaatkan sebagai obat. Gaharu bisa dipakai sebagai obat: anti asmatik, anti mikroba, stimulant kerja syaraf dan pencernaan, obat sakit perut, perangsang nafsu birahi, penghilang rasa sakit, kanker, diare, tersedak, tumor paru-paru, obat tumor usus, penghilang stres, gangguan ginjal, asma, hepatitis, sirosis, dan untuk kosmetik (perawatan wajah dan menghaluskan kulit) (Soehartono 2001).

Tingginya nilai ekonomis gaharu, maka eksplorasi di hutan alam tidak dapat terkontrol dengan baik. Mengingat tingginya nilai gaharu dan juga kelangkaannya, maka budidaya gaharu semakin mendesak. Upaya membuat hutan Aquilaria spp., dapat dilakukan dengan mudah. Tumbuhan Aquilaria sp. relatif mudah di kembangbiakan dan toleran dengan lokasi ekstrim. Untuk mendapatkan pertumbuhan tanaman gaharu yang baik maka diperlukan hara yang cukup. Soeparto (1977) menyatakan bahwa pemupukan adalah penambahan unsur hara yang dibutuhkan tanaman guna meningkatkan produksi dan mutu hasil. Eksploitasi hutan alam tropis dan perburuan gaharu yang tidak terkendali mengakibatkan spesies-spesies gaharu menjadi langkah.

Dalam pemenuhan permintaan pasar, semua produksi gaharu masih mengandalkan dari hutan alam. Jika tidak diatasi pengadaan plasma nutfahnya, maka akan mengancam kelestarian jenis gaharu itu sendiri jika pengawasan relatif rendah dan nilai jual gaharu relatif tinggi. Kegiatan ini dapat menimbulkan intensitas perburuan gaharu di hutan alam semakin tidak terkendali. Karena kurangnya pengetahuan dalam membedakan pohon berisi dan tidak 
berisi gubal gaharu mengakibatkan masyarakat pemungut gaharu menebang pohon secara spekulatif. Pohon gaharu yang telah ditebang ternyata tidak mengandung gaharu setelah dikupas dan dicacah, kemudian akan diterlantarkan begitu saja. Jika hal ini berlangsung secara terus menerus dan tidak adanya upaya pelestarian ataupun kebijakan tentang pemanenan gaharu, maka populasi gaharu akan semakin terancam punah.

Untuk mengatasi kelangkaan, dibutuhkan upaya konservasi melalui kegiatan pemanfaatan secara lestari dan pelestarian jenis beserta ekosistemnya. Oleh sebab itu perlu dilakukan kegiatan budidaya pada spesies pohon penghasil gaharu untuk mendukung kebutuhan masyarakat dunia secara berkelanjutan sebagai penghasil devisa negara (Sumarna 2012). Penelitian ini bertujuan untuk mengetahui respon pertumbuhan semai gaharu (Aquilaria malaccensis) terhadap pemberian pupuk organik, dimana melalui hasil penelitian ini diharapkan dapat memberikan informasi bagi semua kalangan terkait penggunaan pupuk organik yang tepat pada anakan pohon penghasil gaharu (Aquilaria malaccensis).

\section{METODE PENELITIAN}

Penelitian ini dilaksanakan selama 3 bulan yaitu, bulan Juni sampai dengan bulan Agustus tahun 2015 yang berlokasi pada lahan persemaian yang ditempatkan pada Asrama Mahasiswa UNIPA yaitu Asrama Metroxylon. Metode yang digunakan dalam penelitian ini adalah metode eksperimen yang dilakukan dengan Rancangan Acak Lengkap (RAL). Menggunakan semai Aquilaria malacensis umur satu tahun dengan perlakuan yang dilakukan terdiri dari 3 perlakuan, setiap perlakuan di ulang sebanyak tiga kali. Semai yang diujicobakan: $3 \times 3=9$ satuan percobaan. Setiap satuan percobaan terdiri dari 20 unit percobaan sehingga dibutuhkan semai Aquilaria sebanyak $9 \times 20=180$ unit percobaan.

Model matematis dari rancangan RAL menurut Hanafiah (2004) adalah sebagai berikut:

$$
\mathbf{Y i j}=\boldsymbol{\mu}+\mathbf{P i}+\varepsilon \mathbf{i j}
$$

Dimana

Yij = Hasil akibat perlakuan ke-i pada ulangan ke-j

$\mu=$ Nilai tengah umum

$\mathrm{Pi}=$ Pengaruh faktor perlakuan ke-i

zij = Eror akibat perlakuan ke-i pada ulangan ke-j

\section{Prosedur Penelitian}

\section{a. Persiapan Media Tanam}

Pada tahap awal pertumbuhan di lapangan bibit pohon penghasil gaharu memerlukan naungan. Persiapan berupa pembuatan naungan dengan ukuran10 $\times 10 \mathrm{~m}^{2}$. Perlakuan media yang akan diberikan pada penelitian ini ada 3 perlakuan yaitu:

$>$ Tanah top soil (kontrol) yang diberi kode $\mathrm{K}$

Tanah top soil yang dicampur dengan pupuk kandang dengan perbandingan volume 1:1 diberi kode P.

$>$ Tanah top soil dicampur dengan pupuk kandang yang telah ditambahkan $\mathrm{EM}_{4} \quad$ (Effective Microorganisms 4) yang telah difermentasikan selama \pm 1 minggu dengan perbandingan volume 1:1 E.

b. Pemindahan Anakkan Semai Gaharu

Dari Polybag ke Polybag

Proses pencampuran media dilakukan secara manual dengan menggunakan 
sekop. Pencampuran media dilakukan secara bertahap dengan mencampurkan media semai hingga merata dari polybag ke polybag. Setelah media disiapkan selanjutnya media diisi ke dalam polybag, kemudian semai dimasukkan ke dalam polybag tersebut.

c. Pemeliharaan

Pemeliharaan meliputi : penyiangan dan penyiraman. Penyiangan dilakukan jika muncul rumput atau gulma dalam polybag yang digunakan untuk menanam semai Aquilaria malaccensis. Penyiraman dilakukan pada pagi dan sore hari. Namun pada saat hujan penyiraman tidak dilakukan.

\section{Teknik Pengambilan Data}

Data yang akan diambil dalam penelitian ini meliputi meliputi faktor pertumbuhan antara lain tinggi tanaman, diameter tanaman, dan jumlah cabang. Pengukuran tinggi, diameter dan jumlah cabang dilakukan setiap satu minggu. Selain itu dilakukan pengukuran juga terhadap perubahan suhu dan kelembaban yang pengukurannya dilakukan pada pagi hari sekitar pukul 06.00 WIT dan pada sore hari sekitar pukul 18.00 WIT.

\section{Variabel Yang Diamati}

\section{a. Pertumbuhan Tanaman}

Tinggi tanaman

Pengukuran tinggi semai $A$. malaccensis akan dilakukan dari batas leher akar sampai pada pucuk anakan. Pertambahan tinggi semai diperoleh dari hasil pengukuran tinggi semai akhir pengukuran tinggi semai terakhir dikurangi tinggi semai awal dalam centimeter $(\mathrm{cm})$.
Pengukuran diameter semai $A$. malaccensis akan dilakukan $5 \mathrm{~cm}$ di atas leher akar. Pertambahan diameter semai diperoleh dari hasil pengukuran diameter semai akhir pengukuran diameter semai terakhir dikurangi diameter semai awal dalam centimeter $(\mathrm{cm})$.

Jumlah cabang

Jumlah cabang yang akan dilakukan dalam pertumbuhan ini adalah jumlah cabang yang terdapat pada semai A. malaccensis.

\section{Analisis Data}

Analisis data yang digunakan dalam penelitian ini adalah analisis varian (ANOVA) Rancangan Acak Lengkap (RAL). Jika ada pengaruh yang signifikan dari perlakuan yang diberikan maka akan dilanjutkan dengan uji kontras ortogonal, pada tingkat kepercayaan 95\%. Data hasil penelitian akan disajikan dalam bentuk tabel, grafik dan gambar.

\section{HASIL DAN PEMBAHASAN}

\section{Hasil}

Hasil penelitian respon pertumbuhan semai gaharu ( $A$. malaccensis) terhadap pemberian pupuk organik menunjukkan ketiga media memberikan dukungan terhadap pertumbuhan tinggi semai gaharu.

\section{Pertumbuhan Tinggi Semai Gaharu}

Media tumbuh pupuk organik adalah campuran pupuk kandang dengan tanah top soil dan campuran top soil, pupuk kandang dan EM4+. Kedua pada media tanam pupuk organik dibandingkan dengan media tumbuh top soil ditampilkan pada tabel 1 . 
Tabel 1. Respon pertumbuhan tinggi semai gaharu yang ditanam pada media top soil dan pupuk organik

\begin{tabular}{|c|c|c|c|c|c|}
\hline \multirow{3}{*}{ No. } & \multirow{3}{*}{ Perlakuan } & \multicolumn{3}{|c|}{ Tinggi $(\mathrm{cm})$} & \multirow{3}{*}{$\begin{array}{c}\text { Rerata } \\
(\mathrm{cm})\end{array}$} \\
\hline & & \multicolumn{3}{|c|}{ Ulangan } & \\
\hline & & 1 & 2 & 3 & \\
\hline 1. & Kontrol & 6,01 & 6,56 & 5,26 & 5,95 \\
\hline 2. & Pupuk Kandang+ Top Soil & 11,67 & 7,05 & 4,53 & 7,75 \\
\hline 3. & Pupuk Kandang +EM4+Top Soil & 3,75 & 4,67 & 3,82 & 4,08 \\
\hline
\end{tabular}

Berdasarkan tabel 1., hasil penelitian menunjukkan bahwa pemberian campuran pupuk kandang dan top soil pada media semai gaharu memberikan nilai rerata terbaik $7,75 \mathrm{~cm}$. Nilai rerata terbaik kedua ditunjukkan oleh media kontrol dengan nilai $5,95 \mathrm{~cm}$ dan rerata dengan nilai terendah dimiliki oleh media campuran pupuk kandang, EM4+ dan top soil yaitu $4,08 \mathrm{~cm}$. Rata-rata pertumbuhan tinggi semai gaharu yang ditanam pada media organik dibandingkan dengan kontrol disajikan pada gambar 1.

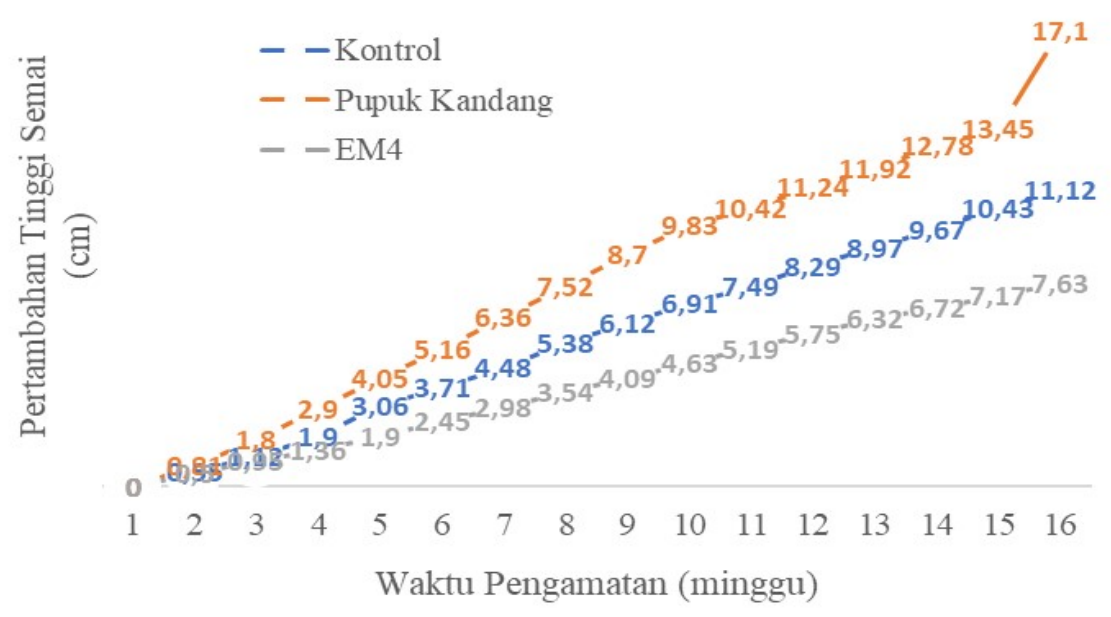

Gambar 1. Rata-rata pertumbuhan tinggi semai pada media pupuk organik

Hasil analisis varian respon organik dan media kontrol disajikan pada pertumbuhan tinggi gaharu pada media tabel 2.

Tabel 2. Anova respon pertumbuhan tinggi gaharu yang di tanam pada media top soil dan pupuk organik

\begin{tabular}{lcccc}
\hline Sumber Keragaman & Db & KT & F Hitung & Sig \\
\hline Perlakuan & 2 & 10,102 & 2,196 & 0,192 \\
Galat & 6 & 4,600 & & \\
Total & 8 & & & \\
\hline
\end{tabular}

*Selang kepercayaan 0,05 
Suatu perlakuan dikatakan berpengaruh nyata jika nilai signifikan lebih kecil dari nilai $\alpha(\operatorname{Sig}<\alpha)$. Data tabel 2 menunjukkan bahwa tidak ada perbedaan yang nyata antara ketiga perlakuan yang diberikan terhadap pertambahan tinggi semai gaharu. Dimana nilai signifikan 0,192 lebih besar dari pada nilai $\alpha$ yaitu 0,05 .

\section{Pertumbuhan Diameter Semai Gaharu}

Pertumbuhan diameter adalah bertambahnya diameter batang mulai dari awal pengamatan hingga akhir pengamatan. Pengamatan pertumbuhan diameter semai gaharu selama 16 minggu. Hasil penelitian disajikan pada tabel 3 .

Tabel 3. Respon pertumbuhan diameter semai gaharu yang ditanam pada media top soil dan pupuk organik

\begin{tabular}{|c|c|c|c|c|c|}
\hline \multirow{3}{*}{ No. } & \multirow{3}{*}{ Perlakuan } & \multicolumn{3}{|c|}{ Diameter $(\mathrm{cm})$} & \multirow{3}{*}{$\begin{array}{l}\text { Rerata } \\
(\mathrm{cm})\end{array}$} \\
\hline & & \multicolumn{3}{|c|}{ Ulangan } & \\
\hline & & 1 & 2 & 3 & \\
\hline 1. & Kontrol & 0,18 & 0,23 & 0,71 & 0,37 \\
\hline 2. & Pupuk Kandang+ Top Soil & 0,07 & 0,08 & 0,12 & 0,09 \\
\hline 3. & Pupuk Kandang +EM4+Top Soil & 0.04 & 0,06 & 0,14 & 0,08 \\
\hline
\end{tabular}

Tabel 3 menunjukkan bahwa rata-rata pertumbuhan diameter tertinggi dimiliki oleh perlakuan kontrol yaitu $0,37 \mathrm{~cm}$ sedangkan perlakuan media campuran pupuk kandang dan top soil dan media campuran pupuk kandang, EM4 dan top soil memiliki nilai rata-rata pertumbuhan masing-masing $0,09 \mathrm{~cm}$ dan $0,08 \mathrm{~cm}$. Rata-rata pertumbuhan diameter semai gaharu yang ditanam pada media organik dibandingkan dengan kontrol disajikan pada gambar 2 .

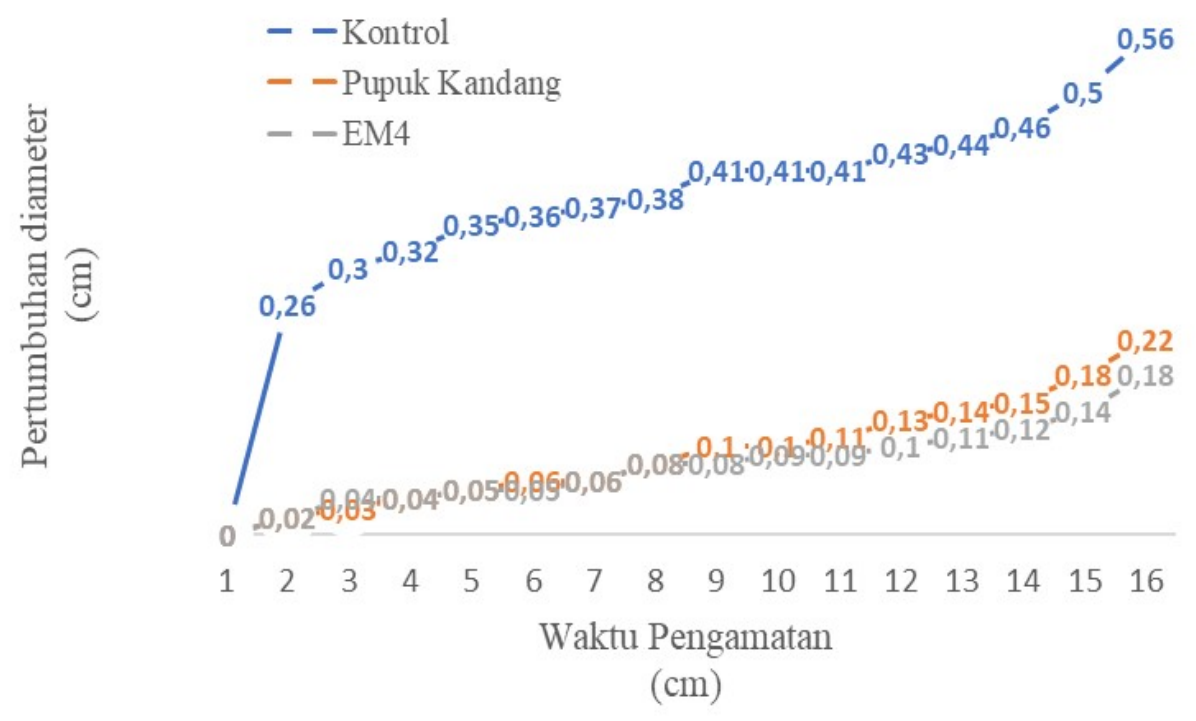

Gambar 2. Rata-rata pertumbuhan diameter semai pada media pupuk organik 
Hasil analisis varian respon pertumbuhan diameter semai gaharu pada media organik dan media kontrol disajikan pada tabel 4 .

Tabel 4. Anova respon pertumbuhan diameter semai gaharu yang di tanam pada media top soil dan pupuk organik

\begin{tabular}{lcccc}
\hline \multicolumn{1}{c}{ Sumber Keragaman } & Db & KT & F Hitung & Sig \\
\hline Perlakuan & 2 & 0,083 & 2,801 & 0,138 \\
Galat & 6 & 0,030 & & \\
Total & 8 & & & \\
\hline
\end{tabular}

*Selang kepercayaan 0,05

Suatu perlakuan dikatakan berbeda nyata bila $\mathrm{F}$ hitung lebih kecil dari nilai $\mathrm{F}$ tabel atau nilai signifikan lebih kecil dari selang kepercayaan $(0,05)$ pada data olahan SPSS. Data tabel 4 menunjukkan bahwa tidak ada perbedaan yang nyata antara ketiga perlakuan yang diberikan terhadap pertambahan diameter semai gaharu. Dimana nilai signifikan 0,138 lebih besar dari 0,05 .

\section{Pertumbuhan Percabangan Semai Gaharu}

Pertumbuhan percabangan adalah bertambahnya cabang semai mulai dari awal pengamatan hingga akhir pengamatan. Pengamatan pertumbuhan percabangan semai gaharu selama 16 minggu yang disajikan pada tabel 5 .

Tabel 5. Respon pertumbuhan percabangan semai gaharu yang ditanam pada media top soil dan Pupuk Organik

\begin{tabular}{|c|c|c|c|c|c|}
\hline \multirow{3}{*}{ No. } & \multirow{3}{*}{ Perlakuan } & \multicolumn{3}{|c|}{ Tinggi (cabang) } & \multirow{3}{*}{$\begin{array}{c}\text { Rerata } \\
\text { (cabang) }\end{array}$} \\
\hline & & \multicolumn{3}{|c|}{ Ulangan } & \\
\hline & & 1 & 2 & 3 & \\
\hline 1. & Kontrol & 3 & 1 & 5 & 3 \\
\hline 2. & Pupuk Kandang+ Top Soil & 3 & 3 & 3 & 3 \\
\hline 3. & Pupuk Kandang +EM4+Top Soil & 1 & 1 & 1 & 3 \\
\hline
\end{tabular}

Tabel 5 menunjukkan bahwa rata-rata pertumbuhan percabangan pada perlakuan pemberian campuran pupuk kandang dan top soil dan perlakuan kontrol dimana nilai rata-ratanyan sama yaitu 3 cabang. Media campuran pupuk kandang, EM4 dan top soil memiliki nilai rata-rata pertumbuhan lebih rendah yaitu 1 cabang. Rata-rata pertambahan percabangan semai gaharu yang ditanam pada media organik dibandingkan dengan kontrol disajikan pada gambar 3 . 


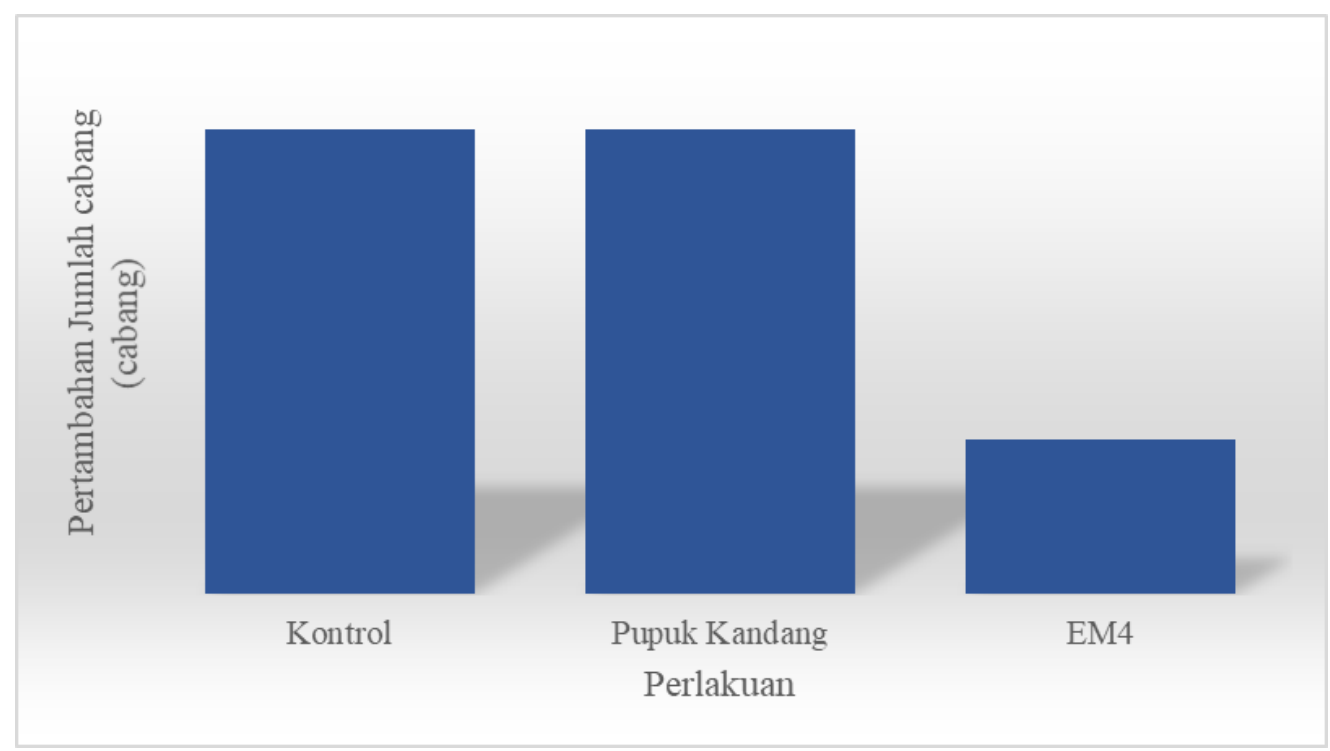

Gambar 3. Rata-rata jumlah cabang semai gaharu pada media pupuk organik

Hasil analisis varian respon percabangan semai gaharu pada media organik dan media kontrol menunjukkan bahwa tidak ada perbedaan yang nyata antara ketiga perlakuan yang diberikan terhadap pertambahan jumlah cabang semai gaharu. Dimana nilai signifikan 0,127 lebih besar dari 0,05 .

\section{Pembahasan}

Respon variabel pertumbuhan baik tinggi, diameter dan percabangan yang ditunjukkan oleh semai gaharu. Tanah sebagai media pertumbuhan dan perkembangan tanaman tidak dengan sendirinya dapat menunjang keberhasilan usaha penanaman dikarenakan berbagai pengaruh yang diberikan tanah bagi kelangsungan pertumbuhan tanaman. Pengaruh yang diberikan tanah antara lain temperatur, kelembaban, permeabilitas, tersedianya unsur hara, kegiatan jasad renik dan banyak sifat tanah lainnya (Sutedjo dkk. 1996). Arsyad dkk. (2012) menjelaskan bahwa pemupukan merupakan salah satu usaha pengelolaan kesuburan tanah. Dengan hanya mengandalkan ketersediaan hara pada tanah saja tanpa penambahan hara, produk pertanian akan semakin merosot. Hal ini disebabkan adanya ketidakseimbangan antara pasokan hara dan kebutuhan tanaman. Hara dalam tanah secara berangsur-angsur akan berkurang karena pencucian tanah, air limpasan permukaan, erosi atau penguapan (Nismawati dkk. 2013).

Pupuk kandang merupakan hasil dekomposisi kotoran ternak oleh aktivitas mikroorganisme pengurai menjadi bentuk yang sederhana dan dapat dimanfaatkan untuk memperbaiki kesuburan tanah (Prananda dkk. 2014). Pemberian pupuk kandang pada media tumbuh semai dapat memperbaiki sifat fisik dan sifat kimia tanah selain itu juga dapat memperbaiki kesuburan tanah. Hakim (1986) dalam Prananda dkk. (2014) menyatakan bahwa pemberian kompos ke dalam tanah dap at memperbaiki struktur tanah, meningkatkan daya serap air, memperbaiki aliran udara di dalam tanah, 
meningkatkan ketahanan terhadap erosi serta meningkatkan kesuburan tanah dengan menambah unsur hara yang dibutuhkan tanaman. Bahan organik yang berasal dari pupuk kandang merupakan bahan yang paling baik dalam memperbaiki sifat fisik tanah. Pupuk kandang mengandung semua unsur hara esensial yang diperlukan tanaman (Setyorini dkk. 2003). Pemberian pupuk kandang pada media tanam semai dapat memberikan kelembaban dan mengurangi resiko erosi berupa retakan pada media tumbuh. Minardi (2014) menyatakan bahwa pemberian bahan organik mampu meningkatkan memperbaiki kelembaban tanah.

Kotoran hewan yang dicampur dengan Effective Microorganisms 4 (EM4+) menghasilkan hasil fermentasi atau peragian bahan organik yang menyerupai kompos. Keunggulan penggunaan teknologi EM4+ adalah pupuk organik dapat dihasilkan dalam waktu yang relatif singkat dibandingkan dengan cara konvensional (Wasis dan Baskara 2013). Juliana (2011) menyatakan bahwa kompos merupakan material yang menyediakan sumber nutrient penting yang mendukung pertumbuhan dan perkembangan mikroorganisme.

Parameter tinggi merupakan parameter yang paling sederhana dalam pengamatan pertumbuhan tanaman karena tinggi merupakan parameter untuk mengetahui pengaruh lingkungan ataupun perlakuan yang diberikan. Hasil penelitian menunjukkan bahwa tidak ada perbedaan yang nyata antara tinggi, diameter dan percabangan tanaman pada ketiga perlakuan yang diberikan. Hal ini diduga dikarenakan proses fisiologis yang terjadi pada semai yang diuji belum diproses secara maksimal. Handayani
(2009) menyatakan bahwa pertumbuhan setiap tanaman dipengaruhi oleh proses fisiologi yang terjadi di dalam tubuh tanaman tersebut. Proses fisiologi tersebut dapat berupa proses fotosintesis, respirasi tumbuhan, translokasi dan penyerapan air serta mineral (Wasis dan Baskara 2013).

Pertumbuhan diameter berlangsung apabila keperluan hasil fotosintesis untuk respirasi, penggantian daun, pertumbuhan akar dan tinggi telah terpenuhi (Hildalita 2009). Pada ketiga perlakuan di atas, kebutuhan hasil fotosintesis untuk memenuhi kebutuhan pertumbuhan tinggi masih belum terpenuhi secara optimal sehingga pertumbuhan diameter dan percabangan tidak dapat terlihat hasil yang jelas. Volume air yang tidak sama pada saat penyiraman kemungkinan menyebabkan terjadinya pencucian pada saat volume air terlalu banyak, dan pada saat volume air terlalu sedikit semai gaharu akan kekurangan air sehingga pertumbuhannya tidak optimal. Selain itu, selama penelitian berlangsung temperatur udara di lokasi penelitian cukup tinggi yaitu sekitar $30{ }^{\circ} \mathrm{C}-33{ }^{\circ} \mathrm{C}$ dan kelembaban yang cukup rendah $50-60 \%$ sehingga mempengaruhi proses metabolisme semai. Beberapa semai yang ditanam pada perlakuan media campuran pupuk kandang, EM4+ dan top soil menunjukkan gejala kematian dimana daun menjadi layu, satu persatu gugur dan daun mulai kering. Hal inilah yang menyebabkan nilai rata-rata pada perlakuan media ini menjadi sangat turun drastis.

\section{DAFTAR PUSTAKA}

Arsyad AR, Junedi H dan Farni Y. 2012. Pemupukan kelapa sawit berdasarkan potensi produksi untuk meningkatkan 
hasil tandan buah segar (TBS) pada lahan marginal kumpeh. Jurnal Penelitian Universitas Jambi Seri SAINS, Vol 14 (1): 29-36.

Departemen Kehutanan. 2004. Profil pengusahaan gaharu. Pusat Bina Penyuluhan Kehutanan. Jakarta.

Hanafiah KA. 2004. Rancangan percobaan. Jakarta: PT Raja Grafindo Persada.

Handayani M. 2009. Pengaruh dosis pupuk NPK dan kompos terhadap pertumbuhan bibit salam (Eugenia polyantha.Wight) [Skripsi]: Fakultas Kehutanan. Institut Pertanian Bogor.

Hildalita. 2009. Penggunaan sludge pabrik kopi dalam produksi semai jabon (Anthocephalus cadamba Roxb Miq.). [Skripsi]: Fakultas Kehutanan. Bogor: IPB.

Juliana M. 2011. Karakteristik fisik dan kimia kompos bokasih, arang sekam, dan arang kayu terhadap penyerapan gas amoniak (NH3). [Skripsi]: Fakultas Teknologi Pertanian. Bogor.

Minardi S, Hartati S dan Pardono P. 2014. Imbangan pupuk organik dan arorganik pengaruhnya terhadap hara pembatan dan kesuburan tanah lahan sawah bekas galian $\mathrm{C}$ pada hasil jagung (Zea mays L). Jurnal Ilmu Tanah dan Agroklimatologi, 11 (2): 122-129.

Nismawati, Wulandari $\mathrm{R}$ dan Irmasari. 2013. Pengaruh pemberian berbagai dosis bokhasi terhadap pertumbuhan semai Kemiri (Aleurites moluccana (L.) Willd.). Jurnal Warta Rimba Vol. 1 (1): 1-7.

Prananda R, Indriyanto dan Riniarti M. 2014. Respon pertumbuhan bibit jabon (Anthocephalus cadamba Roxb Miq.) dengan pemberian kompos kotoran sapi pada media penyapihan. Jurnal Sylva Lestari, 2 (3): 29-38.

Setyorini D, Widowati LR dan Adiningsih SJ. 2003. Kurva respon pemupukan fosfat untuk padi sawah pada berbagai kelas status hara tanah. hlm. 1 - 16. Dalam Prosiding Seminar Nasional Inovasi Teknologi Sumber daya Tanah dan Iklim. Bogor, 14 - 15 Oktober 2003. Pusat Penelitian dan Pengembangan Tanah dan Agroklimat.

Situmorang J dan Yupi, 2005. Perbanyakan pohon gaharu (Aquilaria spp.) Unggul secara vegetatif, kultur jaringan dan stek. Pelatihan Nasional Budidaya dan Pengolahan Gaharu, Seameo Biotrop 28 - 30 November 2005.

Soehartono TR. 2001. Gaharu kegunaan dan pemanfaatan. Disampaikan pada Lokakarya Tanaman Gaharu di Mataram tanggal $4-5$ September 2001.

Soeparto P. 1977. Vedemekum perkebunan. Direktoral Jenderal Perkebunan, Departemen Pertanian. Jakarta.

Sumarna Y. 2005. Budidaya gaharu, Seri Agribisnis Penebar Swadaya - Jakarta.

Sumarna Y. 2007. Budidaya dan rekayasa produksi gaharu. Temu Pakar Pengembangan Gaharu. Direktorat Jenderal RLPS, Jakarta.

Sumarna, Y. 2009. Gaharu- Budidaya dan Rekayasa Produksi. Penebar Swadaya - Jakarta. Hal 1-76.

Sumarna Y. 2012. Budidaya jenis pohon penghasil gaharu. Badan Penelitian dan Pengembangan Kehutanan Pusat Litbang Produktifitas Hutan Bogor.

Sutedjo MM, Kartasapoetra AG dan Sastroatmodjo S. 1996. Mikrobiologi tanah. Rineka Cipta: Jakarta. 
Wasis B dan Baskara H. 2013. Winarsih A, Puspita F dan Khoiri MA. Pertumbuhan semai nyatoh (Palaquium spp.) pada media tailing PT. Antam Unit Bisnis Pongkor pada penambahan arang tempurung kelapa dan pupuk kompos bokashi. Jurnal Silvikultur Tropika, 4 (1): 1-5.

2011. Pengaruh stressing terhadap percepatan pembentukan gubal gaharu pada tanaman gaharu (Aquilaria malaccencis, Lamk.). [Skripsi]: Fakultas Pertanian, Universitas Riau. 